\title{
Reform of the European Electoral Law
}

\author{
by Friedrich Pukelsheim und Kai-Friederike Oelbermann
}

On 4 December 2014 the Committee on Constitutional Affairs of the European Parliament conducted a public hearing on the reform of the European Election Act, actually its first hearing during the legislative period 2014-2019. Among the experts invited were the present authors, who report on the meeting. For the translation of votes into seats they propose a double-proportional procedure securing electoral equality with regard to the political preferences of all voters in the Union as well as guaranteeing each member state its preordained seat contingent. Double-proportionality becomes feasible, however, only when the European party system reaches a level allowing the aggregation of all votes across the whole Union.

Die erste öffentliche Anhörung der Legislaturperiode 2014-2019, die der Ausschuss für konstitutionelle Fragen des Europäischen Parlaments durchführte, fand am 4. Dezember 2014 statt und galt der Reform des Europäischen Wahlakts. Die Autoren, die zu den eingeladenen Sachverständigen zählen, berichten von der Sitzung. In ihrer Stellungnahme skizzieren sie für die Sitzzuteilung ein doppeltproportionales Verfahren, das hinsichtlich aller Wählerstimmen die politischen Präferenzen nach dem Grundsatz der Wahlgleichheit abbildet und hinsichtlich der Mitgliedstaaten die vorab bestimmten Sitzkontingente garantiert. Der Doppelproporz kann allerdings erst umgesetzt werden, wenn das europäische Parteiensystem so weit entwickelt ist, dass es der unionsweiten Aggregation aller Wählerstimmen einen Rahmen gibt.

\section{AFCO Committee's Public Hearing on 4 December 2014}

The Committee on Constitutional Affairs is a standing committee of the European Parliament. Parliamentary jargon calls it AFCO Committee, AFCO being an acronym derived from the French affaires constitutionnelles. ${ }^{1}$ Besides a November workshop on Challenges in Constitutional Affairs in the New Term, the public hearing on the Reform of the European Electoral Law on 4 December 2014 in Brussels was the first formal hearing organized by the AFCO Committee in the legislative period 2014-2019, thus testifying to the topic's prominence. AFCO chairwoman Danuta Hübner (EPP-PL) suggested structuring the analysis of further electoral reform around the following categories of intervention:

1 www.europarl.europa.eu/committees/en/afco/events.html. 
- Practical arrangements not requiring changes to the law in order to strengthen the visibility of the European elections and the public awareness thereof;

- Changes to secondary law: Right to vote and stand as a candidate in elections to the European Parliament for citizens of the Union residing in a member state of which they are not nationals (Regulation 93/109/EC as amended);

- Measures implementing the Election Act proposed by the European Parliament and adopted by the Council after consulting the Commission (Article 14 Election Act);

- Changes to the Election Act in order for example to establish a level playing field for parties and candidates;

- Changes to the Treaties for example to modify the number of Members of Parliament with a view to introduce transnational lists.

The rules of the European Parliament limit the number of speakers a committee may invite to a hearing to four. The AFCO Committee invited Yves Bertoncini (Notre Europe - Institut Jacques Delors, Paris), Roberto D'Alimonte (Libera Università Internazionale degli Studi Sociali Guido Carli, Rome), Brendan O'Leary (University of Pennsylvania, Philadelphia), and the first of the present authors who teamed up with the second. An additional distinguished speaker was Andrew Duff (Cambridge), Member of the European Parliament 1999-2014 and AFCO rapporteur on electoral procedure in former legislative periods.

Expert hearings in the German Bundestag and the European Parliament differ significantly in their function. In the Bundestag, a hearing constitutes the final action of a decision-making process. Typically a committee organizes a hearing just before the topic is concluded and handed over to the plenum, only after each political group has determined their stance and made their proposals public. Experts are expected not so much to contribute finding an optimum solution, but rather to endorse the committee's ingenuity and to praise the existing proposals. Such expectations are rarely met. The event may entail a bit of frustration on all sides and, accordingly, attendance often leaves something to be desired.

In the European Parliament, hearings are among the first actions in a committee's decision-making process. The theme of electoral reform has a long history, of course, but for the sitting AFCO Committee the December hearing marked the start of its work on the subject. Interest and open-mindedness of those present was noticeable during the presentation of the experts' statements as well as during the ensuing discussion. For the most time the meeting room, seating 160, was 
packed with committee members and their staff, besides a few public. Because of the early stage of the hearing and in the absence of definite commitments by the political groups, the opinions of the experts covered a rather broad range of relevant aspects.

In a nutshell, the experts emphasized the following points. Andrew Duff appealed to incumbent committee members: Do try to be more bold! The aim ought to be to call another convention, in order to install transnational lists and to adjust the balance of power between the Union's institutions. Brendan O'Leary presented two visions. In his confederal vision he recommended the status of times past when members of the Common Assembly were delegated by the member states' parliaments, thus furthering parliamentary collaboration at Union and domestic levels. In his federal vision he questioned the need for more uniformity in the Election Act, notwithstanding the establishment of a European Electoral Authority. Roberto D'Alimonte pointed out that a common electoral law is not absolutely essential as it would neither increase voter turnout nor the Parliament's legitimacy. The significant differences in size of member states is a reality and cannot be overcome by legal provisions, though double-proportionality might be worth considering. Yves Bertoncini pointed out that electoral systems go hand in hand with parliamentary practice. Placing more emphasis on political parties would make sense only when the Parliament would divide into a government majority versus an opposition minority. Currently the European Parliament rather resembles the scheme of a great coalition, in that it usually aims at carrying decisions by the broadest possible consensus. Our own statement, of which the essentials are reproduced in Part II, was entitled Reinforcing Uniformity in the European Election Act: Gentle Interim Arrangements in 2019 towards Systematic DoubleProportionality in 2024. We proposed a double-proportional method for the translation of votes into seats first presented in this journal. ${ }^{2}$

It remains to be seen which actions the AFCO Committee will take on the grounds of this hearing and its forthcoming deliberations.

2 Oelbermann, K.-F./Pukelsheim, F.: Future European Parliament Elections. Ten Steps Towards Uniform Procedures, in: ZSE, 9 (2011), 9-28. See also Chapter 14 in Pukelsheim, F.: Proportional Representation. Apportionment Methods and Their Applications, with a Foreword by Andrew Duff MEP, Cham (CH), 2014. 


\section{Reinforcing Uniformity in the Election Act}

Section 1 argues that the fatal defect of current European Parliament elections, the misdirection of the electorate, will only be overcome provided unionwide political parties emerge to contest the election and to carry the electoral campaign. Sections 2 and 3 assume that such a European party system comes into being. Section 2 describes a double-proportional method for the translation of votes into seats that fits the Union's constitutional frame perfectly. Doubleproportionality is illustrated by means of the 2009 election results, in tables 1 and 2. Due to the lack of unionwide parties in 2009 , the illustrations necessitate some practically unrealistic alignments. Section 3 proposes three interim arrangements for 2019 that might pave the way to introduce systematic double-proportionality in 2024 .

\section{What is the Problem? Misdirection of the Electorate}

The biggest defect of the current electoral system ${ }^{3}$ is that it misdirects the electorate. The election campaign focuses on political leaders who shape the political scene of a member state, but who are known not to compete for a seat in the European Parliament. Voters are handed ballot sheets listing political parties that are part of the domestic sphere of a member state, but that are virtually invisible in the political work of the European Parliament. The 186 domestic parties ${ }^{4}$ that are presented to the Union's electorate eventually boil down to a handful of political groups that shape Parliament's daily routine, but that are not presented to the electorate. To quote but one source from the literature: There is a "mismatch" between the institutional role the European Parliament is asked to play in the European Union's separation of powers - the voice of European citizens about European Union politics - and the level of party competition at which European Parliament elections are contested. ${ }^{5}$ Therefore, if the European Parliament de-

3 The elections are governed by the 1976 Election Act, as amended in 2002. A consolidated version of the Election Act is included as Annex II in: Report (A7-0176/2011, 28.07.2011) on a proposal for a modification of the Act concerning the election of the Members of the European Parliament by direct universal suffrage of 20.09.1976 (2009/2134(INI)), Rapporteur: Andrew Duff, European Parliament 2009-2014, RR \865675EN.doc, PE440.210v04-00.

4 Hrbek, R.: Europawahl 2014. Kontinuität und neue Facetten, in: Integration, 37 (2014), 205-227, here 217.

5 Schleicher, D.: What If Europe Held an Election and No One Cared?, in: Harvard International Law Journal, 52 (2011), 109-161, here 110. Schleicher corroborates his "mismatch thesis" in detail and at length with many persuasive arguments. As a remedy he proposes a re-design of ballot sheets and the introduction of unionwide thresholds; these proposals are followed up in our Section 3. 
sires to inject more uniformity into its Election Act, then an indispensable necessary prerequisite is the establishment of unionwide parties to play a proper role in elections, or so it would seem to us. There is an abundance of literature on the subject, by political scientists, by constitutional lawyers, and by practicing politicians. ${ }^{6}$ Being mathematicians it is beyond our competence to comment upon how to create a unionwide party system. Instead we assume that unionwide political parties will come into existence and will be ready to contest elections. Under this assumption we propose a scheme of translating votes into seats that fits the Union's constitutional frame perfectly, double-proportionality.

Before continuing we briefly digress and specify the term unionwide party, for our purposes. We give it a less restrictive meaning than the term political parties at European level that appears in the regulation regarding party funding. ${ }^{7}$ Our notion of a unionwide party is to indicate a political organization that observes, in particular in its programme and in its activities, the principles on which the European Union is founded and that has participated or intends to participate in elections to the European Parliament. This is all we require. In most cases a unionwide party will be active in two or more member states, at best in all of them. However, the definition admits a unionwide party to be present in just a single member state. The reason is that the system should also accommodate newly emerging parties which cannot but start small.

\section{What is the Solution? Double-Proportionality, starting 2024}

Double-proportionality apportions parliamentary seats with regard to two dimensions, how the electorate is divided by political parties and how it is partitioned into territorial districts. What does double-proportionality look like when applied to the European Parliament? The political dimension captures the performance of the unionwide parties, of course. The territorial dimension consists of the allocation of Parliament's seats between the member states of the Union. In the jargon of the Union's primary law this is referred to as the composition of the European

6 We quote but three: Hix, S.: What's Wrong with the European Union and How to Fix It, New York, 2008; Huber, P.M.: Demokratische Legitimation in der Europäischen Union, in: ZSE, 7 (2009), 364-380; Priestley, J.: European Political Parties. The Missing Link, Notre Europe Policy Paper 41, Paris, 2010.

7 Regulation (EC) No 2004/2003 of the European Parliament and of the Council of 04.11.2003 on the regulations governing political parties at the European level and the rules regarding their funding. Official Journal of the European Union, L 297 (15.11.2003), 1-4. See also Leinen, J./Pescher, F.: Von Parteibündnissen zu echten Parteien auf europäischer Ebene? Hintergrund, Gegenstand und Folgen der neuen Regeln für Europäische Parteien, in: Integration, 37 (2014), 228-246. 
Parliament. ${ }^{8}$ Double-proportionality is manageable no matter how the composition is brought about, whether it emerges from a negotiated political fix as in the past, or whether it is obtained by a durable and transparent formula. Doubleproportionality requires some set of seat contingents for the member states to be preordained, but any set will do.

Double-proportional apportionment methods proceed in two steps, called superapportionment and sub-apportionment. The super-apportionment reflects the political dimension of the division of the electorate: all disposable seats are apportioned in proportion to the vote totals of the unionwide parties. A sample super-apportionment is shown in table 1, re-evaluating the 2009 elections in a double-proportional manner. ${ }^{9}$ Since unionwide parties did not exist in 2009 , we replace them by the political groups that were formed at the beginning of the legislative period. The vote total of a political group is taken to be the aggregation of the votes cast for the domestic parties that joined this group. The nonattached members are assembled in a pseudo-group NA. Thus table 1 encompasses all 144.244.444 votes that effectively entered into the 2009 seat allocation calculations.

Table 1: Sample 2009 double-proportional seat apportionment: Super-apportionment of 751 seats among eight political groups

\begin{tabular}{|lrrr|}
\hline EP2009DP & Votes & Quoticnt & Divstd \\
Super-apportionment & & & 272 \\
\hline FPP & 52324413 & 272 & 191 \\
S\&D & 36776044 & 191.3 & 84 \\
ALDE & 16058094 & 83.55 & 63 \\
GREENS/EFA & 12070029 & 62.8 & 40 \\
ECR & 7610712 & 30.6 & 37 \\
EFD & 7153584 & 37.2 & 33 \\
GUE/NGL & 6280876 & 32.7 & 31 \\
NA & 5970692 & 31.1 & 751 \\
\hline Sum (Union divisor) & 144244444 & $(192200)$ & \\
\hline
\end{tabular}

Calculations are based on the unionwide votes for the 2009 political groups, in lieu of the nonexisting votes for unionwide parties. Normally the group of non-attached seats (NA) would require a

8 Article 14(2) EU Treaty, see: Consolidated Version of the Treaty on European Union. Official Journal of the European Union, C 83 (30.03.2010), 13-45.

9 This is Table 14.5 in Pukelsheim, F.: Proportional Representation, op.cit. For the unionwide aggregation of the political groups' vote counts see also Oelbermann, K.-F./Pukelsheim, F.: Future European Parliament Elections, op.cit. 
separate handling. Sample calculation: The EPP votes (52.324.413) are divided by the union divisor (192.200). The quotient 272.2 justifies 272 seats.

Table 2: Sample 2009 double-proportional seat apportionment: Sub-apportionment by political groups and member states.

\begin{tabular}{|c|c|c|c|c|c|c|c|c|c|}
\hline \multicolumn{2}{|c|}{ EP2009DP EPP } & $\begin{array}{r}S \& D \\
191\end{array}$ & $\begin{array}{r}\text { ARDE } \\
84\end{array}$ & GRE/EFA & $\begin{array}{r}\mathrm{ECR} \\
40\end{array}$ & $\begin{array}{r}\mathrm{EFD} \\
37\end{array}$ & $\begin{array}{c}\text { GUE/NGL } \\
33\end{array}$ & $\begin{array}{r}N A \\
31\end{array}$ & tet \\
\hline DE 06] & 00681594 & 517256628 & 288808112 & 310450013 & & & $1060230 \%$ & & 251000 \\
\hline FF, 85 & $4799908-30$ & $2838160-18$ & $1458841-9$ & $2803759-16$ & & $257437-2$ & $915634-0$ & $89184-5$ & 60000 \\
\hline UK 82 & & $2460249-16$ & $2080613-13$ & $1767218-11$ & $4131386-18$ & $2498226-17$ & $6184-11$ & $1181845-6$ & 2000 \\
\hline Im $\mathrm{sol}$ & 12066334230 & 700775024 & 24766057 & & & 212541810 & & & 000 \\
\hline $\operatorname{los} 62$ & $6670357-28$ & $6141784-25$ & $808246-3$ & $6894662-3$ & & & $244124-1$ & $40.866-2$ & 3000 \\
\hline PI, 52 & $37 \times 7098.23$ & 90876548 & & & $2017607-11$ & & & & 1000 \\
\hline 031 & $2074012-14$ & $1504218-10$ & $702074-5$ & & & & & $410094-2$ & 1000 \\
\hline 26$]$ & $913233-6$ & $548691-4$ & 1034 & 41 & $155270-1$ & -1 & $y-2$ & $7(2746-4$ & 5000 \\
\hline FI. 19 & $1655729-7$ & 187808028 & & & & & & & 800 \\
\hline BE: 19 & $1288422-4$ & $1259998-4$ & $64-4$ & $1319342-4$ & 290 & & & 64 & 000 \\
\hline T 18 & $1427300-8$ & $946475-6$ & & & & & $761718-4$ & & 178000 \\
\hline OZ 18 & $180451-2$ & $528132 * 6$ & & & $7 \times 13$ & & $7 \times 4$ & & 87000 \\
\hline U 18 & $1632309-11$ & $503140-3$ & & & 153 & & & $427773-3$ & 151000 \\
\hline sक $1 \%$ & $744851-5$ & $773513-5$ & 60309.3 & 575029.3 & & & -1 & & 172700 \\
\hline AT 16 & & 0800 & & 284 & & & & $9-5$ & 170000 \\
\hline BG 14 & 8 & 47 & 569 & & & & & $308052-2$ & 160000 \\
\hline DK12 & & $503439-3$ & 171041-2 & $371603-2$ & & 357 & $5-1$ & & 200000 \\
\hline $\operatorname{Sr} 12$ & $324081-6$ & $204722 \times 4$ & $71241-1$ & & & $45960-1$ & & & 61530 \\
\hline FI 12 & 3 & 9020 & .3 & 20 & & 1620 & & & 0050 \\
\hline$\left|\begin{array}{ll}\mid \mathrm{E} & 11\end{array}\right|$ & & & $525375-3$ & 345850 & & 997001 & $256123-1$ & & 158000 \\
\hline$\left|\begin{array}{ll}\text { LT } & 9\end{array}\right|$ & & $102347-2$ & 88870.2 & & $46293-1$ & $67237-1$ & & & 50000 \\
\hline$\left|\begin{array}{ll}\mathrm{ST} & \mathrm{g}\end{array}\right|$ & & 24072 & 084502 & & & & & & 50000 \\
\hline Ly 8 & & & $6-1$ & & 5899 & & 774447 & & 80000 \\
\hline $\mathrm{EE}=7$ & & $608-1$ & $164383-3$ & $116830-2$ & $8860-0$ & $2206 m 0$ & & & 60000 \\
\hline CY 7 & $109200-3$ & $67794-2$ & $12630-0$ & & & & $106022-2$ & & 40000 \\
\hline Le 6 & $62202-2$ & $38641-2$ & $37013-1$ & $33387-1$ & & & & & 26000 \\
\hline MT 6 & $100486-3$ & $135917-3$ & & $5802-9$ & & & & & 41000 \\
\hline Pand & div. 0.9575 & 0.9863 & 1 & 1.011 .4 & i.4\% & 0.934 & 1.065 & 1.13 & \\
\hline
\end{tabular}

Seats are allocated to the political groups in the member states using the double-proportional divisor method with standard rounding. The divisors guarantee each member state its preordained seat contingent, and each political group its party-seats from the super-apportionment. Sample calculation: The German EPP votes (9.968.153) are divided by the DE divisor (251.000), and by the EPP divisor (0.9575). The quotient 41.48 (not shown) justifies 41 seats.

The super-apportionment in table 1 handles all unionwide votes simultaneously and treats them equally, with no regard to member state provenance. Every 192.200 votes justify roughly one seat. The prime benefit of the unionwide seat apportionment is that it secures electoral equality among all Union citizens when votes are taken to express political preferences. ${ }^{10}$ At present, electoral equality is

10 An added benefit is the facilitation for a state to subdivide its area into electoral districts, compare McLean, I.: Don't Let the Lawyers Do the Math: Some Problems of Legislative Districting in the UK and the USA, in: Mathematical and Computer Modelling, 38 (2008), 1446-1454. 
strangely absent in the Union's primary law. ${ }^{11}$ However, the Treaties are full of promises to observe equality among Union citizens, all member states subscribe to electoral equality being one of the five principles underlying Europe's electoral heritage, ${ }^{12}$ and the European Convention for the Protection of Human Rights and Fundamental Freedoms to which the Union shall accede ${ }^{13}$ values electoral equality highly. We propose that the Union grants its citizens a free, equal, and secret ballot. This is our only plea for a change to the Treaties.

The double-proportional seat apportionment concludes with the subapportionment of seats by unionwide parties and member states. This second step is more laborious since it must verify two conditions: the party-seats from the super-apportionment must be met, as must be the preordained seat contingents of the member states. table 2 shows the sample re-evaluation of the 2009 elections. The party names and their overall seats are copied from the super-apportionment into the table's top row, the left column exhibits member states and their seat contingents. ${ }^{14}$ The seats of a state's party are obtained via double division and rounding: The pertinent vote count is divided by the associated state divisor and by the associated party divisor, and then the resulting quotient is rounded to the nearest whole number. It may be checked that the seat numbers thus obtained sum columnwise to the party's overall seats and rowwise to the State's seat contingent, as desired. In summary, double-proportionality appears to suit the Union's needs perfectly. The task is to find ways and means to get there.

While the main obstacle remains the creation of a system of unionwide parties, other issues also require attention when ballots are aggregated across the whole Union: the varied ballot structures that are entertained by the 28 member states. Most of the required harmonization can be achieved at low cost. However, ballot sheets from single transferable vote systems constitute a problem. These systems put a particular emphasis on the personalization aspects of an election, as op-

11 On the other hand Di Fabio, U.: Entwicklungsperspektiven für das Europäische Parlament, in: ZSE, 12 (2014) 9-17, here 12, finds that the principle of electoral equality "need not hold, in fact strictly speaking must not hold, without shifting the character of a compound of states adversely to its conception towards a federal state" (our translation). Article 14(3) EU Treaty reads: "The members of the European Parliament shall be elected for a term of five years by direct universal suffrage in a free and secret ballot."

12 Council of Europe, European Commission for Democracy through Law (Venice Commission): Code of Good Practice in Electoral Matters - Guidelines and Explanatory Report, Opinion no. 190/2002, CDLAD (2002) 23 rev. Strasbourg, 23.05.2003.

13 Article 6(2) EU Treaty.

14 These contingents total 751 seats and result from the Cambridge Compromise, see Section 14.9 in Pukelsheim, F.: Proportional Representation, op.cit. They differ from the actual 2009 seat contingents. 
posed to focusing on political parties. A common denominator with the proportional representation systems used by other member states might be the introduction of open lists (where not in use already). ${ }^{15}$ The issue needs careful consideration, but we do not pursue it here further. Moreover any re-design of ballot sheets should foster e-voting which will become indispensable in future elections in view of the ever increasing mobility of society.

\section{How to Get There? Three Interim Arrangements for $\mathbf{2 0 1 9}$}

The establishment of unionwide parties that competently and attractively contest European Parliament elections may need more time than provided by a legislative period of five years. Ten years should suffice though. Therefore we suggest decreeing double proportionality now, to start in 2024. The European Parliament would join the company of many other parliaments that are used to pass significant electoral amendments with the proviso that these take effect, not in the current legislative period, but in the next.

For the next election in 2019 we propose three interim arrangements that will encourage the formation of unionwide parties. The three proposals could be incorporated into the Election Act. The first two, a Europeanized ballot design (a) and the introduction of unionwide thresholds (b), would continue to apply in the long run. The third item, transnational lists (c), is a transitional measure for 2019 only, because it becomes redundant once double-proportionality is adopted.

\section{a) Ballot Design}

The first proposal is that ballot sheets must exhibit the emblem and name of the unionwide party to which a domestic party is affiliated ahead of the emblem and name of the domestic party itself. Presumably the existing political parties at European level serve as germs from which unionwide parties will grow. Hence many domestic parties know already now to which unionwide party they will become affiliated, and could comply with the proposal quite readily. Nonaffiliated parties will have a ballot box preceded by white space and thus expose their missing European outlook. In this way information on the ballot sheets will no longer be restricted to the domestic sphere. During the election campaign parties will advertise their ballot boxes to inform their supporters. The new de-

15 Hix, S./Hagemann, S.: Could Changing the Electoral Rules Fix European Parliament Elections?, in: Politique européenne, 28 (2009), 27-41. 
sign will spread and induce voters to sense a European perspective. Altogether it will be easier than now for voters to develop a clear and consistent opinion of their European options.

\section{b) Threshold Cascade}

The second proposal intends to award domestic parties for their efforts to acquire the status of a unionwide party and to expand into several member states. The idea is to lower the maximum 5\% threshold of article 3 of the Election Act depending on how a party's support spreads across the Union. By way of example the threshold cascade may take the following form: Throughout the Union valid votes for a party become effective (that is, enter into the seat apportionment calculations) only when the party attracts at least

- $5 \%$ of the valid votes in one member state;

- $\quad$ or $4 \%$ of the valid votes in each of two member states;

- $\quad$ or $3 \%$ of the valid votes in each of four member states;

- $\quad$ or $2 \%$ of the valid votes in each of eight member states.

The threshold cascade does not apply to votes for independent candidates; effectiveness of these votes could be left to be settled in domestic provisions.

\section{c) Transnational Lists}

The third proposal offers unionwide parties a concrete reward to strive for, namely seats contested at Union level rather than contested within the member States' domains. Transnational lists, having been present in the discussion for quite some time, figure prominently in this Committee's 2011 report. ${ }^{16} \mathrm{We}$ elaborate on the idea with the understanding that it will become outdated as soon as double-proportionality takes over for good. In view of the transitional nature of the measure its one-time implementation in 2019 ought to leave the Treaties alone and comply with current primary law. We sketch an approach how this could be achieved.

16 Item 2 on page 7 of the Report reads: "[The European Parliament] proposes that an additional 25 MEPs be elected by a single constituency formed of the whole territory of the European Union; transnational lists would be composed of candidates drawn from at least one third of the States, and may ensure an adequate gender representation; each elector would be enabled to cast one vote for the EU-wide list in addition to their vote for the national or regional list; voting for the EU constituency would be in accordance with the closed list proportional system [...]." 
Our approach is contingent on the composition of the European Parliament being derived from a durable and transparent formula as afforded by the Cambridge Compromise or one of its variants. ${ }^{17}$ When compared to the sitting Parliament's composition it transpires that about 25 or 26 seats need to be re-allocated. ${ }^{18}$ Most of these seats are transferred from middle-sized member states to bigger states. We propose that these seats are not handed out to the target states. Instead, they are set aside to be apportioned via transnational lists, as outlined in the 2011 report.

At first glance the proposal seems to put an undue burden on the (mostly bigger) member states that would profit from the transfer. On second thoughts the burden may well be softened by the outcome of the transnational seat apportionment. For when composing their transnational lists, unionwide parties will have to reach out for their prospective voters. Three quarters of the Union's citizens live in the seven biggest member states. Transnational lists cannot but feature plenty of nominees from the big member states, perhaps not three quarters of all candidates, but certainly not much less than half of them. In essence, most of the transnational list seats will eventually be filled with nominees from the bigger member states. ${ }^{19}$ This looming imbalance makes us doubt whether transnational lists, while promising to be an expedient measure in 2019, would stand the test of time in the long run. They certainly cannot compete with the perfect solution offered by double-proportionality.

17 Grimmett, G.R. et.al.: The allocation between the EU Member States of the seats in the European Parliament, European Parliament, Directorate-General for Internal Policies, Policy Department C: Citizen's Rights and Constitutional Affairs, Note 23.03.2011 (PE 432.760). See also Section 12.9 in Pukelsheim, F.: Proportional Representation, op.cit.

18 The limited-loss variant of the Cambridge Compromise affects 25 seats with 2013 QMV-populations, and 26 seats with 2014 population figures. See Table 12.5 in Pukelsheim, F.: Proportional Representation, op.cit., and Annex One in Duff's contribution to the hearing.

19 To evade this imbalance the votes for transnational lists could be evaluated using doubleproportionality, see Section 1.3 in Oelbermann, K.-F.: Biproportionale Divisormethoden und der Algorithmus der alternierenden Skalierung, Berlin, 2013. 